\title{
TRADITIONAL KNOWLEDGE IN COMBATING SAND DUNES (A CASE STUDY IN SIWA OASIS)
}

\author{
(Received:10.11.2010)
}

\author{
By \\ H. M. Tohamy and M. M. Barakat*

\begin{abstract}
Department of Rural Sociology Socio- Economic Division, Desert Research Center and $*$ Department of Rural Sociology and Agricultural Extension, Faculty of Agriculture, Ain-Shams University
\end{abstract}

\begin{abstract}
The present study aimed mainly to document the experience and knowledge of local Bedouins in combating sand dunes and how the projects of combating sand dunes help them in the same area.

The field Study was carried out in Siwa Oasis, Matrouh Governorate, and used five focus group discussions, each group consisted of 7- 8 members (39 member) whom were randomly selected.

The group discussions were done according to the interview guide, which was prepared in advance for this purpose.

The main results show that there are a lot of traditional knowledge in the Siwa culture for combating sand dunes, which were not used by any project aimed to solve the sand dunes problems.
\end{abstract}

Key words: sand dunes, Siwa oasis, traditional knowledge.

\section{INTRODUCTION}

Local knowledge plays an important role in building a bridge between the practical solutions, research and policies in order to achieve sustainable development through using the methodology of participatory development where traditional knowledge is the major resource in development (Grenier, 1998) due to the following reasons:

-Identifying needs and priorities of the community.

-Geting benefit from marginalized group experiences in planning and development models from bottom to top.

-Using the mechanisms and tools based on traditional knowledge The World Bank, 1998 mentioned other reasons as:

- Providing a strategy to solve the local community problems and especially the poor.

- Supporting the development of cultural aspect through the adaptation of international practices at the local level.

- Reducing the costs of the programs and development projects.

- Providing guidelines for policy-makers and the planning of new projects.

The sand dune encroachment is the last stages of desertification, which represent a major threat to most Arab states and some North African countries, and threatens agricultural land, economic institutions and social development in those countries.

Hard climate factors(length of the drought, the lack of rainfall, high summer temperatures) in addition to human assaulting the vegetation cover through some of the negative practices helped in creating a non- stable sensitive ecosystem which help in increasing sand dune encroachment.

Governments make strenuous efforts to resist the negative effects of sand dune encroachment through scientific techniques and methods which aim to temporary installation or permanent, but these technologies face many obstacles of economic, social, technical, and legislative, which lead to non-sustainability of these technologies due to the high costs, the lack of economic feasibility studies for resisting sand dunes encroachment, non-participation of the community members in the planning and implementing those technologies. However, local inhabitants have an enormous amount of traditions knowledge (Draz, 1995).

The current study is trying to inventory the traditions knowledge used by the local population in tolerating sand dunes and building appropriate technologies for the local community.

\subsection{Study problems}

We anticipate to answer the following question:

- What are the effects of the movement of sand dunes from the local population point of view? 
- What are the tools and methods used by the local population to resist proceeding of sand dunes?

\subsection{Goals}

Based on the research problem, the main objective of the study was documenting the traditional knowledge of the local Bedouins in resisting sand dunes encroachment through:

-Identify local expertise of respondents with regard to the effect of sand dunes movement.

-Identify local expertise of respondents with regard to the methods of sand dunes movement resistance.

-Identify the benefits of the applied projects for stabilizing sand dunes in the study area.

\subsection{Study plan}

To achieve the study objectives, a plan was developed including the following elements:

\subsection{The concepts of procedure \\ 1.4.1. Sand dunes}

The phenomenon of sand dune formation is attributed to many environmental and climate factors such as low rainfall, the scarcity of other water resources, high temperatures, high winds, in addition to the density of population activities in marginal areas including: collection of firewood, overgrazing, expansion in cultivating marginal areas (Draz, 1995).

There are a variety of systems and methods used to resist sand dune movement such as:

Temporary fixation: it is considered to be the initial steps of combating sand dune programs and the protection of cultivated plants from mechanical damage caused by wind loaded with sand. The most important techniques and methods used are walls, barriers, covering the soil surface, the use of wind energy. For the implementation of those technologies plant material are used such as reeds and palm fronds, or other materials such as concrete slabs and spun polyethylene, bitumen emulsion, and oil prior.

Permanent Installation (CBD): This technique depends on cultivating plants to reduce wind speed and to protect development areas. The installation program includes several components such as the planting of trees and shrubs, planting seeds after rainfall, the maintenance of planted areas to do its job in stabilizing sand dunes (Ktali, 1988).

\subsubsection{Traditional knowledge}

Alessandro and Fre (2003) defined traditional knowledge as a collection of facts related to associated concepts, beliefs and perceptions. Also it is defined as, the knowledge used by the local people to earn a living, and it is developed according to the community modernization and it is characterized by creativity (Alessandro and Fre 2003). The local knowledge also refers to the traditions, knowledge, teachings and practices of a regional group or community, which are transmitted orally from generation to generation through stories, legends, customs, songs, and laws (Deepak, and Anshu 2008).

Moreover, it is also considered to be a wide range of knowledge and practices related to the local population, and it had been formulated outside the formal educational system to survive, and became an essential part of this community culture (Grenier, 1998).

\section{Properties of local knowledge}

From the above definitions of the concept of traditional knowledge, we can mention the following characteristics:

-Based primarily on experience.

-Tested over the generations.

-Adapt to the local culture and natural environment.

-An essential part of community practices.

-Agreed by individuals or communities.

-Dynamic and variable.

How is Traditional knowledge exchanged?

The integration of IK into the development process is essentially a process of exchange of information from one community to another. The process takes six steps:

1.recognition and identification: Some IK may be embedded in a mix of technologies or in cultural values, rendering them unrecognizable at first glance to the external observer (technical and social analyses may, therefore, be required to identify IK).

2.validation:This involves an assessment of IK's significance and relevance (to solving problems), reliability (i.e., not being an accidental occurrence), functionality (how well does it work?) effectiveness and transferability.

3.recording and documentation: Is a major challenge because of the tacit nature of IK (it is typically exchanged through personal communication from master to apprentice, from parent to child, etc.). In some cases, modern tools could be used, while in other circumstances it may be appropriate to rely on more traditional methods (e.g., taped narration, drawings).

4. storage in retrievable repositories: Storage is not limited to text document or electronic format; it could include tapes, films, story telling, gene banks, etc.

5. transfer: This step goes beyond merely conveying the knowledge to the recipient; it also includes the testing of the knowledge in the new 
environment. Pilots are the most appropriate approach in this step.

6. $\square$ dissemination To a wider community adds the developmental dimension to the exchange of knowledge and could promote a wider and deeper ripple impact of the knowledge transfer (Heli, 2007).

\section{METHODS}

\subsection{The geographical scope of the research}

It is clear that Matruh Governorate is one of the largest governorates that contains large areas of sand dunes specially Siwa Oasis, so the Siwa Oasis in Matrouh has been selected to carry out the study, khamsa, elmraqi and ghzalat areas were selected as one of the areas bordering the dune movement and some projects were implemented to install the movement of sand dunes in them.

\subsection{The sample and type of the study}

The methodology of rapid research appraisal was used in collecting the data of this study through focus group discussions.

Focus group discussion was used in collecting the field data from five groups of targeted respondents; each group contained 7- 8 members, with total respondents 39 . where a recording tapes were used in addition to tables prepared for these discussions.

These respondents were selected randomly taking into consideration the similarity degree in personal characteristics as age, educational level, and agricultural holding. The discussion took place according to the interview guide, which was prepared in advance for this purpose including the three main axes:

-The effects of sand dunes movement.

-. Ways of combating sand dunes movement.

- The degree of benefit gained from the projects which were implemented in the dunes area from the respondents point of view.

The data were analyzed qualitatively which depend on the daily review of the information obtained, summarized and classified and draw conclusions related to the objectives of the study, in addition to tables of frequency distribution and arithmetic average.

\section{RESULTS AND DISCUSSION}

\subsection{The Effects of sand dunes movement}

The focus group discussions showed that:

- The movement of wind causing sand dunes starts in February and ends in April and the wind reaches its maximum speed in March.

-The movement of the wind has a daily cycle, It starts in the morning from the east with a high speed, and in the afternoon comes hot wind from the south which could burn the crops. At sunset a cold wind comes from the west with a little damage while in the evening the wind movement stops completely.

-The majority of the wind directions in the oasis comes from the southern, western and eastern, only the southern winds are hot because they come from the desert, the winds coming from the west only carry sand and lead to cover the plants with sand up to $50 \mathrm{~cm}$ per day.

-Some respondents explained that some seedlings should not be irrigated while the event of sand dunes took place because this may lead to ossification of the sand on the seedlings leading to suffocating.

-The movement of strong winds may lead to break the branches of olive trees and lead to the uprooting vegetable plants such as tomato, in addition to lack of visibility due to sand.

-The majority of respondents indicated that the winds have many benefits for Siwa, it pollinate crops like olives and palm trees as the wind movement transfer pollen.

Table (1) shows the response distribution for the respondents about the negative effects of sand dunes on the various life aspects.

Table (1): Distribution of respondents according to their responses about the negative effects of sand dunes.

\begin{tabular}{|l|l|l|l|l|}
\hline \multirow{2}{*}{ Statement } & \multicolumn{3}{c|}{$\begin{array}{c}\text { The negative effects } \\
\text { of sand dunes }\end{array}$} & \multirow{2}{*}{} \\
\cline { 2 - 4 } & High & Medium & Low & \\
\hline Sustainable Trees & 5 & 9 & 25 & 11.1 \\
\hline $\begin{array}{l}\text { Cultivation of } \\
\text { vegetables }\end{array}$ & 29 & 6 & 4 & 19.8 \\
\hline $\begin{array}{l}\text { Irrigation and } \\
\text { drainage canals }\end{array}$ & 19 & 11 & 9 & 16.9 \\
\hline Housing & 6 & 14 & 19 & 12.5 \\
\hline Public health & 31 & 5 & 3 & 20.3 \\
\hline Agricultural soil & 28 & 6 & 5 & 19.4 \\
\hline Total & & 39 & 100 \\
\hline
\end{tabular}

Source: Data collected in the table were calculated from the focus group discussions' results.

The negative effects of sand dunes on the public health occupied first ranked by $20.3 \%$ from the responses of the respondents, because the movement of grains of soft sand that are stuck in the air lead to breathing difficulties, and chest diseases, especially among children.

-As the table indicates the cultivation of vegetables and agricultural soils were ranked second and third respectively in terms of effectiveness to sand dunes movement, and may be due to the fact that the movement of sand dunes lead to uprooting the plants, vegetables, 
severe drought and possibly burn completely, the sand dunes help in transferring the fertile soil from one place to another also helps in raising the soil salinity.

-The negative effects of sand dunes movement, covering irrigation channels, drains, springs and water wells with sand, causing significant losses in clearing those channels and return them to work again.

\subsection{The experiences of the respondents in combating sand dunes}

The group discussions showed:

-There is an agreement about the existence of a belt of Elhoor trees (Alkerkab, castor) as it is called by the people of the oasis in the western side of the oasis, to protect the bank's main road of Siwa Lake.

-The plant breeding by rhizomes, so the siwan tribes set a legislation that prohibits cutting those trees because of their great importance in stopping the advance of sand dunes on the bank's main road of the lake.

- The majority of respondents depend mainly in facing the movement of sand dunes on the palm trees, olives specially a kind named elweteki due to its drought and resistance to wind. It is planted $3 \mathrm{~m}$ between the rows and in the perpendicular rows from the east to the west side so that it does not slow down the movement of air and do not allow the composition of dunes within the plants.

-The majority of the siwan respondents use (Alzerb) made from palm fronds and olive wood in combating sand dunes and protect crops from children, and to protect and cover the siwa ladies in the farm, it is held (Alzerb) on the east, southern and west side of the farm only, and they do this Alzerb of palm fronds specially local kinds named-Azzawi, Freihi, and Ghazali and the ages of Alzerb are made from the fronds of such items from 15 to 17 years, and the palm fronds Saidi ranges age from 10 to 12 years only because of the weakness and fragility of the palm fronds Saidi.

-After the recovery of tourism in Siwa oasis, many hotels increase their demand for palm leaves. This is why it has been replaced by reeds or Phragmites australis. The ages of (Alzerb) made from Phragmites australis is about 5 to 10 years, and is done by planting palm leaves or Phragmites australis in the occupied status of the vertical depth of $50 \mathrm{~cm}$, and planting the pillars of olive-wood on the dimensions from 4 to 6 meters. Alzerb Fencing is from 5 to 7 pounds per meter if it is created from palm leaves, while the range cost of reeds or Phragmites australis of 3-4 pounds per meter.

-Some respondents use the Casuarina trees in combating sand dunes, individually, or a fence of (Alzerb) is build in front of casuarina trees to protect it during the early years of growth, the casuarina trees are cultivated in two ways, either to be grown in one row with three trees in a meter, or is planted in three rows by five trees per meter.

Table (2) shows the distribution of the respondent responses according to the methods used for sand dune fixation:

-The percentage of respondents who use sustainable trees in combating sand dunes specially palm trees, and olives is $37.8 \%$ from the total respondents, probably due to the spread of cultivating these trees in Siwa oasis and to insurance of their effectiveness in the combating the movement of sand dunes.

Table (2): Distribution of the respondents responses According to the methods used for sand dune fixation.

\begin{tabular}{|l|c|c|}
\hline Installation methods & number & \% \\
\hline Sustainable trees & 34 & 37.8 \\
\hline Plant sources fence & 31 & 34.4 \\
\hline Casuarina & 14 & 15.6 \\
\hline $\begin{array}{l}\text { Casuarina } \\
\text { +Elzerb Fence }\end{array}$ & 11 & 12.2 \\
\hline Mineral oils & 0 & 0.0 \\
\hline $\begin{array}{l}\text { Fences from other } \\
\text { recourses }\end{array}$ & 0 & 0.0 \\
\hline Total & $\mathbf{9 0}$ & $\mathbf{1 0 0}$ \\
\hline \multicolumn{2}{|l|}{$\begin{array}{l}\text { Source Data collected in the table were calculated from } \\
\text { the focus group discussions' results. }\end{array}$}
\end{tabular}

-The percentage of respondents who use the fences to combat sand dunes movement, especially plant sources such as palm leaves and olive wood and reeds is about $34.4 \%$ from the total respondents. This is because of the availability of these waste plants and their low cost compared to any other sources.

-The proportion of respondents who use the Casuarina trees and Alzerb fence to resist the movement of sand dunes is about $15.6 \%, 12.2 \%$, respectively from the total respondents, and the majority of those respondents are investors who planted the sand dune areas, which need greater protection for seedlings at the beginning of agriculture.

-The table shows that no respondents used any method based on mineral oils or other sources this may be due to the high costs of these methods and the absence of respondents' knowledge. 


\subsection{Results of benefit gained by respondents from sand dune fixation projects}

Activities to install the sand dunes on the governmental level takes place through the reconstruction of the north coast in cooperation with the Research Desert Center and the Social Fund for Development and Environmental Affairs Agency. During the period from 1992 to 1996, they adopted the idea of dune fixation by cultivating shrubs bersobes, Acasia and Atriplex halimus. These shrubs were irrigated by drainage water in alkhamsa, and elmraqi where the movement of sand dunes activities, threatens the bank's main road to Siwa Lake and the surrounding plantations bank.

\section{The results of the group distributions are}

-The majority of respondents believe that the benefit of the project was the income of the daily labor that the project used in digging and planting trees only.

-Some respondents indicated that the main reasons of failing such projects was due to the following.

-The project used new kinds of trees in combating sand dunes, and it is used as a good fodder to feed the sheep and camels but rarely there is a presence of grazing animals in the oasis, which weakens the benefit and reduces its spread in the oasis.

-Project mainly irrigate these planted with agricultural drainage water with high salinity, which led to the drought and the death of seedlings, as well as it raise the salinity of the soil.

-Not getting use of the traditional knowledge of the Siwa people in selecting the appropriate type of plants to resist the movement of sand dunes.

\subsection{Recommendations for the organizations (local and national) working in the same field}

-Taking into consideration traditional knowledge in combating sand dunes.

-Traditional knowledge should be taken as a base for new techniques could be used to solve sand dunes problems by inventing solutions accepted by the local people.

\section{REFERENCES}

Alessandro D. and Fre Z. (2003). Understanding the indigenous knowledge and information systems of pastoralists in Eritream, Communication for Eveloment Case Study, 26, FAO.

Deepak A and Anshu, S. (2008). Indigenous Herbal Medicines: Tribal Formulations and Traditional Herbal Practices, Aavishkar Publishers Distributor, Jaipur- India. http://en.wikipedia.org/wiki/Traditional_kn owledge\#cite_note-0

Grenier L. (1998). Working with Indigenous Knowledge. A guide for researchers. IDRC, www.unesco.org/shs/most.

World Bank (1998). Indigenous knowledge for development, a framework for action, Knowledge and Learning Center ,Africa Region.

Heli R (2007). Mapping and Managing Local Knowledge In Urban Planning. International Conference, Sustainable Urban Areas.

$$
\begin{aligned}
& \text { در از،حمد يحيب(1995)، الكثبان الرملية في الوطن العربي و إمكانات }
\end{aligned}
$$

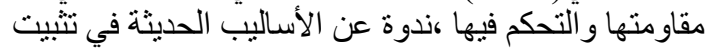

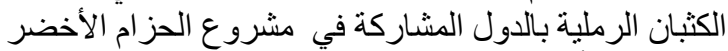

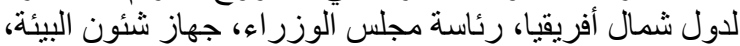

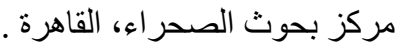

$$
\begin{aligned}
& \text { الختالي، الحسين( 1988)، دليل تنثيت الكثبان الرملية، الدنظمة } \\
& \text { العربية للتربية والثقافة،تونس. }
\end{aligned}
$$




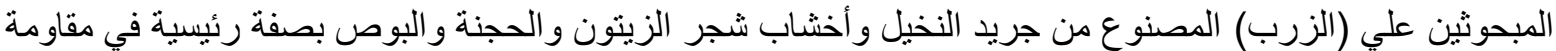

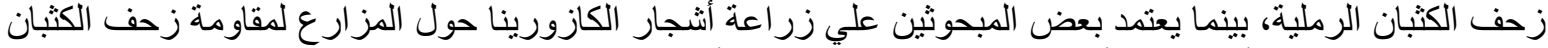

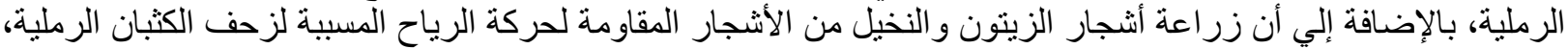

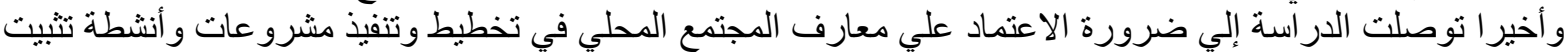

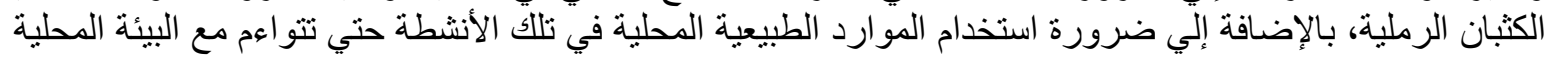

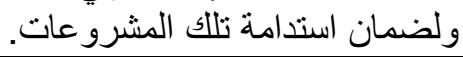
المجلة العلمية لكلية الزراعة - جامعة القاهرة - المجلد (62) العدد الأول ( يناير 2011):28-23. 